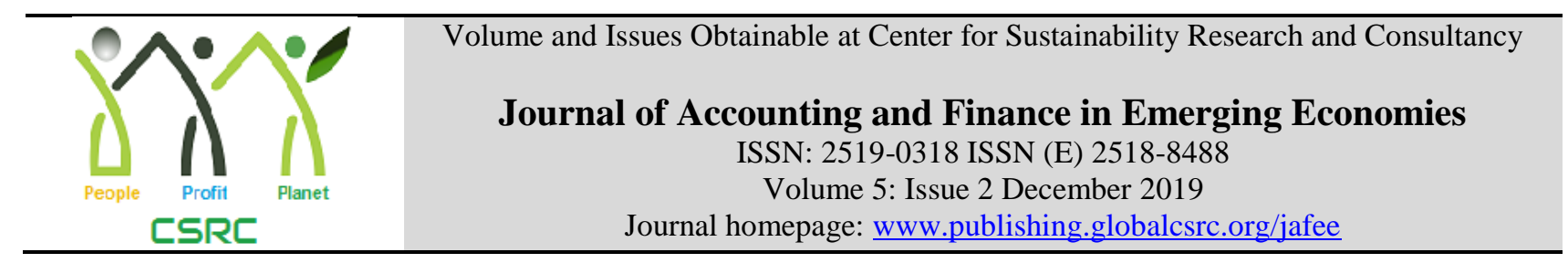

\title{
Balancing hospital's financials through implementing Cost of Quality Models
}

\author{
${ }^{1}$ Malak Aoun, ${ }^{2}$ Hassan Alaaraj \\ ${ }^{1}$ School of Business, Lebanese International University, Lebanon. malak.aoun@liu.edu.lb \\ ${ }^{2}$ School of Business, Lebanese International University, Lebanon. hassan.aaraj@liu.edu.lb
}

\begin{tabular}{l} 
ARTICLE DETAILS \\
\hline History \\
Revised format: November 2019 \\
Available Online: December 2019
\end{tabular}

\section{Keywords}

Cost Of Quality, Finance,

Hospital, Lean Healthcare

JEL Classification:

D61,D69,E62,E69

\section{ABSTRACT}

Purpose: Hospitals integrate different quality improvement models such as lean and cost of quality to identify the wastes resulted from the cost of poor quality and spot the opportunities for improving the cost of good quality. This study reviews the literature related to these two models and highlights its implementation in the healthcare sector.

Design: the study is based on a systematic-review of previous literature and summarizes the best modules and practices of cost of quality in healthcare sector.

Findings: One of the main research implications is that accounting and quality assurance teams have to cooperate and share information to reduce undesirable costs and improve the hospital's financials. However, future studies are encouraged to expand the research empirically to discover hidden costs of quality and implement different improvement quality models to enrich the literature.

Originality: It is a complicated task to balance between reducing the cost and providing a high quality service. This study is targeted for quality, finance and accounting managers and it highlights the main issues for measuring the cost of quality in hospitals.

(C) 2019 The authors, under a Creative Commons Attribution-Non Commercial 4.0

Corresponding author's email address: malak.aoun@liu.edu.lb

Recommended citation: Aoun, M. and Alaaraj, H., (2019). Balancing hospital's financials through implementing Cost of Quality Models. Journal of Accounting and Finance in Emerging Economies, 5 (2), 197-202

DOI: $10.26710 /$ jafee.v5i2.769

\section{Introduction}

Providing a product or a service with high quality that meets the customer's needs is considered as the main target for most organizations. However, the process of achieving such a goal is subject to variety of factors that influence its level of conformance. In the healthcare sector, most of hospitals tend to provide high quality services with the lowest cost as a part of its social and humanity prospects. Meanwhile, there are many factors affecting the quality of healthcare services including patient and provider related factors and environmental factors such as management and leadership, resources, facilities and healthcare financing system (Mosadeghrad, 2014).

Currently, most of healthcare organizations are allocating their budgets to match with the costs of providing healthcare services. As cited by the Alliance for Health Reform (2012), the cost of healthcare services is driven by several factors such as fragmented delivery and financing system, technology diffusion, regulations and mainly the 
quality conflicts that would increase the cost and reduce the value of the service provided. Thus, it is essential for hospitals to find potential quality improvement approaches that consider all cost implications and thus help managers to take better decisions regarding the expenditure on quality-related activities.

By definition, cost of quality (COQ) is a term that is commonly used but frequently misunderstood. It is not always the price of creating a quality product or service. Yet, it is the cost of not adding value due to errors and poor management practices such as reworking, retesting and correction of errors (Ross, 2008). The COQ concept was first developed in the 1950s as a tool for managers to assess quality improvement and profit contributions (Juran, 1951). In general, there are two categories namely, cost of good quality (COGQ) that includes prevention and appraisal costs, and the cost of poor quality (COPQ) that includes the internal and external failure costs (Arabian, 2013).

Specifically, prevention costs result from preventing poor quality and maintaining good quality of production, while appraisal costs are associated with checking conformance of products and services mainly through auditing and evaluation. However, failure costs are related to products and services that do not have conformance to quality standards and customer needs. Faiuler costs are observed prior to production (internal failures) or after delivery (external failures) to the customer (Elbireer, 2010). However, Omachonu et al. (2004) illustrated that as appraisal and prevention costs increase, the quality improves and failure cost decreases. Some examples regarding COQ in healthcare organizations are provided in Table 1.

Table 1: Examples of COQ in Healthcare Organizations.

\begin{tabular}{|l|l|l|l|}
\hline \multicolumn{2}{|l|}{ Cost of Good Quality (COGQ) } & \multicolumn{2}{l|}{ Cost of Poor Quality (COBQ) } \\
\hline Prevention costs & Appraisal costs & Internal failure costs & External failure costs \\
\hline - Salaries and benefits for & - Quality control & - wastes at inventory & - Warranty expenses \\
quality assurance team, & -Verification & level & - Complaints \\
administration and technical & - Supplier rating & - Reeducating staff. & -Delay in reporting test \\
staff & - Quality audits & - Repeat ion of tests & - Eults to clients \\
- Training & - External Quality & - Data entry errors & \\
- Quality planning & Assurance (EQA) & & \\
- Preventive maintenance & surveys & & \\
$\begin{array}{l}\text { contracts for equipments } \\
\text { Office supplies for } \\
\text { documentation and annual } \\
\text { competency assessment }\end{array}$ & & & \\
\hline
\end{tabular}

Source: Zahar (2015), Duffy (2013), Elbireer (2010), Zimak (2000)

In hospitals, seven non-value adding activities can increase the cost of poor quality as identified by lean healthcare practitioners namely; overproduction, over processing, transportation, waiting, inventory, motion, unclear communication and correction of errors (HPP, 2011; Burke, 2011; Robbins, 2009; Bicheno \& Holweg, 2009, Womack et al., 2005). By definition, lean healthcare is a set of practices that engage employees to eliminate wastes, identify root causes, solve problems and standardize the work through controlling hospitals' resources in line with the customers' requirements at high quality, less cost and short lead time (Aoun, 2015). Consequently, the objective of this study is to highlight the best employed approaches to improve the hospital's financials through reviewing previous literature and empirical studies that have focused on implementing lean practices to control COQ in healthcare organizations.

\section{Literature Review}

The COQ is considered as a tool to determine the optimal level of quality investment, where COQ analysis enables organizations to identify, measure and control the consequences of poor quality and utilize their limited resources (Tsai et al., 2012). It is essential to assess the effectiveness of quality methods applied to determine opportunities, threats, problem areas and action priorities. Philip Crosby argued that organizations choose to pay for poor quality as he used the model of COQ to describe the monetary impact of quality issues and referred it to the price of nonconformance (Crosby, 1979). Moreover, Duffy (2013) stated that in a successful organization, costs of poor quality may represent about 10 to 15 percent of operations while other studies showed that cost of poor quality 
presents up to $70 \%$ of the total cost of quality as shown in Table 2 (Zimak, 2000). Thus, effective quality improvement programs can reduce such a lost and make a direct contribution to profits.

Table 2: Overall COQ, COGQ and COPQ percentages relative to operating expenses in different hospitals.

\begin{tabular}{|c|c|c|c|c|c|c|c|}
\hline \multirow[t]{2}{*}{ Study } & \multirow{2}{*}{$\begin{array}{l}\text { Overall COQ } \\
\text { from } \mathrm{OE}\end{array}$} & \multirow{2}{*}{$\begin{array}{l}\text { COGQ of } \\
\text { Total COQ }\end{array}$} & & & \multirow{2}{*}{$\begin{array}{l}\text { COPQ of } \\
\text { Total } \\
\text { COQ }\end{array}$} & \multirow[b]{2}{*}{ Internal } & \multirow[b]{2}{*}{ External } \\
\hline & & & Prevention & Appraisal & & & \\
\hline $\begin{array}{l}\text { Menichino } \\
\text { (1992) }\end{array}$ & $35 \%$ & $10 \%$ & & & $25 \%$ & & \\
\hline Zimak (2000) & & & $5 \%$ & $\begin{array}{l}20 \% \\
25 \%\end{array}$ & $\begin{array}{ll}65 \% & - \\
70 \% & -\end{array}$ & & \\
\hline Zahar (2015) & $32 \%$ & $94 \%$ & $24 \%$ & $70 \%$ & $6 \%$ & $4 \%$ & $2 \%$ \\
\hline
\end{tabular}

Note: COQ: cost of quality, COGQ: cost of good quality and COPQ: cost of poor quality, OE: operating expenses.

According to Arabian et al. (2013), there are five common COQ models namely prevention - appraisal - failure (PAF) model, the process cost model (PCM), opportunity or intangible cost model, Crosby's model and activitybased costing (ABC) model. Although PAF model was found to be the most popular model, quality managers are encouraged to select the COQ model that best fit the condition, environment, objectives and organization' needs.

In the same context, Schiffauerova and Thomson (2006) conducted a review of research reviewed on COQ models and best practices and summarized their finding in Table 2 below.

Table 2: Generic COQ models and cost categories

\begin{tabular}{|c|c|c|}
\hline $\begin{array}{l}\text { Generic } \\
\text { model }\end{array}$ & $\begin{array}{l}\text { Cost/activity } \\
\text { categories }\end{array}$ & $\begin{array}{c}\text { Examples of publications describing, analyzing or } \\
\text { developing the model }\end{array}$ \\
\hline $\begin{array}{l}\text { P-A-F } \\
\text { models }\end{array}$ & $\begin{aligned} & \text { prevention } \\
+ & \text { appraisal } \\
+ & \text { failure }\end{aligned}$ & $\begin{array}{l}\text { Feigenbaum, 1956; Purgslove and Dale, 1995; Merino, } \\
\text { 1988; Chang et al., 1996; Sorquist, 1997b; Plunkett and } \\
\text { Dale, 1988b; Tatikonda and Tatikonda, 1996, Bottorff, } \\
\text { 1997; Israeli and Fisher, 1991, Gupta and Campbell, } \\
\text { 1995; Burgess, 1994; Dawes, 1989; Sumanth and Arora, } \\
\text { 1992; Morse, 1983; etc. }\end{array}$ \\
\hline $\begin{array}{l}\text { Crosby's } \\
\text { model }\end{array}$ & $\begin{array}{l}\text { conformance } \\
+ \text { non-conformance }\end{array}$ & Suminsky, 1994; Denton and Kowalski, 1988 \\
\hline \multirow{4}{*}{$\begin{array}{l}\text { Opportunity } \\
\text { or intangible } \\
\text { cost models }\end{array}$} & $\begin{array}{l}\text { prevention } \\
+ \text { appraisal } \\
+ \text { failure } \\
+ \text { opportunity }\end{array}$ & $\begin{array}{l}\text { Sandoval-Chavez and Beruvides, 1998; Modarres and } \\
\text { Ansari, } 1987\end{array}$ \\
\hline & $\begin{array}{l}\text { conformance } \\
+ \text { non-conformance } \\
+ \text { opportunity }\end{array}$ & Carr, 1992; Malchi and McGurk, 2001 \\
\hline & $\begin{array}{l}\text { tangibles } \\
+ \text { intangibles }\end{array}$ & Juran et al., 1975 \\
\hline & $\begin{array}{l}\text { P-A-F } \\
\text { (failure cost includes } \\
\text { opportunity cost) }\end{array}$ & Heagy, 1991 \\
\hline $\begin{array}{l}\text { Process cost } \\
\text { models }\end{array}$ & $\begin{aligned} & \text { conformance } \\
+ & \text { non-conformance }\end{aligned}$ & $\begin{array}{l}\text { Ross, 1977; Marsh, 1989; Goulden and Rawlins, 1995; } \\
\text { Crossfield and Dale, } 1990\end{array}$ \\
\hline ABC models & $\begin{aligned} & \text { value-added } \\
+ & \text { non-value-added }\end{aligned}$ & $\begin{array}{l}\text { Cooper, 1988; Cooper and Kaplan, 1988; Tsai, 1998; } \\
\text { Jorgenson and Enkerlin, 1992; Dawes and Siff, 1993; } \\
\text { Hester, } 1993\end{array}$ \\
\hline
\end{tabular}

Source: Schiffauerova and Thomson (2006) 
Different studies applied these COQ models in healthcare organizations and obtained significant result such as Menichino (1992) who found that quality improvement programs which are based on COQ analysis have reduced the costs of non-conformance by $83 \%$ in a period of 9 months.

Also, Blegen et al., (1995) found in their 18 months-long study that improving the quality of care at a tertiary-level university hospital has reduced the average length of stay by $13.5 \%$ ( 0.7 days) and the average costs decreased by $13.1 \%$ (\$518). In addition, patients' perception of healthcare quality increased from 4.26 to 4.41 based on a 1-5 scale. Furthermore, Malchi and McGurk (2001) measured the alternative or hidden costs of total COQ in a pharmaceutical company. The hidden cost represents the lost sales, delays, extra inventory and unidentified scrap where implementing COQ model led to $11 \%$ reduction in the total COQ.

Crosby (1979) believes that each defect represents a hidden cost such as inspection time, wasted material and labor, rework, lost revenue and the cost of customer dissatisfaction. However, the magnitude of these costs can be made apparent when these deficits are properly identified. Thereby, the concept of lean healthcare is to recognize, reduce and eliminate wastes once the problem occurs, to help cut costs, improve patient services and ensure most advantageous utilization of existing resources (Jekiel, 2011; Patton, 2009; Casey, 2007).

There are many lean tools that have been addressed by previous studies to implement lean philosophy in hospitals mainly kaizen, quick changeover, poka-yoke, just-in-time, jidoka, andon, kanban, and hoshin kanri (Aoun, 2015; Weber, 2013, Ortiz, 2012; Aikens, 2011; Shah \& Ward, 2007). For example, Esimai (2005) examined how lean sixsigma reduces medication errors at a hospital's pharmacy department. Based on the findings, she estimated labor cost reductions of $\$ 1.32$ million annually and a 55\% reduction in medication errors where the total number of errors dropped from 213 in February to 96 errors in June.

Moreover, Olivier and Seyedzadeh (2006) referred to lean implementations while using the cost of poor quality to drive process improvement in medical institutions. They focused on the importance of enhancing automated test equipment (Jidoka) and to reduce errors with process design changes (poka-yoke). Furthermore, the healthcare performance partners (HPP, 2012) have implemented different lean healthcare tools to reduce wastes and cut cost at an emergency department. Upon using the value stream mapping tool, the hospital saved $\$ 230000$ and patient waiting time decreased by $59 \%$ where total patient time in the department dropped to two hours.

In addition, the HPP team employed the lean workplace redesign methodology that presents the $5 \mathrm{~S}$ principles to remove wastes. The study achieved a $43 \%$ in overall waste reduction, $30 \%$ increase in care related activities and $12 \%$ decrease in wasted motion. Likewise, Lowe (2013) showed how successful the Kaizen promotion office at Park Nicollet Health Services in Minnesota was in implementing lean principles. Over two years of lean efforts, 1431 excess inventory items were removed; cycle time was reduced by 76 hours per day and 3977 defects were eliminated per day.

\section{Improvement of Healthcare Financials}

As it is financially approved, the net operating income (NOI) represents the long-term financial viability of hospitals that is mainly the result of deducting the hospital's total operating expenses from the total revenues obtained. If sustained NOI margins are below 2 to $3 \%$ of total operating costs, hospitals are considered to fail financially (Palmer et al., 2006). Therefore, it is essential for hospitals to manage the costs and maintain an acceptable range of NOI to ensure its sustainability in the healthcare market.

Globally, costs of operations in healthcare sector are either fixed or variable costs. Fixed costs are the expenses paid regardless the number of patients, while variable costs are directly proportional to patient number. For instance, as the number of patients increases, the hospital has to count more medications and disposable equipments. However, Researchers have found that 84 to $89 \%$ of hospitals' costs fall in the fixed cost category (Graves, 2004; Roberts et al., 1999). Furthermore, Pudło and Szabo (2014) illustrated how the operating income is highly affected by the variation of revenue and operating expenses at organizations which majority of its costs is fixed. As operating expenses increase, the revenue and operating income decrease. Thus, it is essential for hospitals to manage the operating expenses and reduce the wasted costs in order to increase its revenue and benefits for the long term.

As discussed earlier, integrating lean and COQ models would effectively reduce wasteful operations that narrow the profit margins and potentially lead to poor quality services. Thus, implementing such process improvements 
would improve operations and provide hospitals with necessary information for identifying the potential savings to be gained. Scotty (2013) stated that accountants lack the necessary information for connecting waste with expense accounts. Meanwhile, quality auditors may not have access to ledgers. Therefore, it is very important to have cooperation between accounting and quality assurance staff to estimate the cost of quality and develop strategies for financial and operational improvement.

\section{Conclusion}

In conclusion, it is apparent from previous literature how costs of poor quality and wasteful operations reduce profit margins and inhibit hospitals from having the potential of generating the true revenue. Therefore, providing lean and COQ trainings to accounting staff and facilitating the accessibility of quality assurance team to ledger would help to fill the information gap and build a direct linkage to enhance the hospitals' financials. Future studies can expand this study empirically and provide more case studies to support the literature in terms of applied COQ and quality improvement models. "

\section{References}

Aikens, C. (2011). Quality inspired management: The key to sustainability. New Jersey: Pearson Education, Inc

Alliance for Health Reform. (2012). Cost drivers in health care. Health Policy Alternatives: Washington. Retrieved from http://www.allhealth.org/publications/Cost_of_health_care/Cost_Drivers_in_Health_Care_109.pdf

Aoun, M. (2015). The mediating effect of soft TQM on the relationship between lean practices and innovation skills in Lebanese hospitals. Doctoral dissertation. University Utara Malaysia: Malayisa.

Arabian, T., Jourabchi, S. M., Leman, Z., \& Ismail, M. Y. (2013). A research on the impact of cost of quality models and reporting system on managing cost of quality. International Proceedings of Economics Development and Research, 59: 50.

Bicheno, J., and Holweg, M. (2009). The lean toolbox: The essential guide to lean transformation. 4th ed. Buckingham: PICSIE Books.

Blegen, M. A., Reiter, R. C., Goode, C. J., \& Murphy, R. R. (1995). Outcomes of hospital-based managed care: A multivariate analysis of cost and quality. Obstetrics \& Gynecology, 86(5):809-814.

Burke, J. (2011). John Burke's Education Project: Lean in education. Retrieved from http://jbep.blogspot.com/search?updated-min=2011-01-01 T00:00:00Z\&updated-max=2012-01-

01T00:00:00Z\&max-results=3. Accessed May 2016.

Casey, J. (2007). A lean enterprise approach to process improvement in a healthcare organization. Massachusetts: Massachusetts Institute of Technology. Retrieved from http://dspace.mit.edu/handle/1721.1/42345

Crosby, P.B. (1979). Quality is free. New York: McGraw-Hill

Duffy, G. (2013). The ASQ quality improvement pocket guide: basic history, concepts, tools, and relationships. ASQ Quality Press, 62-65.

Elbireer, A., Gable, A. R., \& Jackson, J. B. (2010). Cost of quality at a clinical laboratory in a resource-limited country. Laboratory Medicine, 41(7):429-433.

Esimai, G. (2005). Lean six sigma reduces medication errors. Quality Progress, I: 51-57

Graves, N. (2004). Economics and preventing hospital-acquired infection. Emerging Infectious Diseases, 10(4):561-566.

HPP. (2011). Lean healthcare philosophy. Healthcare Performance Partners. Available at: http://www.hpp.bz/leanhealthcare/leanhealthcare.php. Accessed May 2016

HPP. (2012). Lean healthcare case studies. Healthcare Performance Partners. Available at: http://leanhealthcareperformance.com/leancasestudies.php. Accessed May 2016.

Jekiel, C. (2011). Lean human resources: Redesigning HR processes or a culture of continuous improvement. New York: Taylor and Francis Group, Productivity Press

Juran, J.M. (1951). Juran's Quality Handbook. 1st ed. New York: McGraw-Hill.

Lowe, F. R. (2013). Lean healthcare: Controlling cost through better care. Doctoral dissertation. University of Minnesota. 
Malchi, G., and McGurk, H. (2001). Increasing value through the measurement of the cost of quality (CoQ): A practical approach. Pharmaceutical Engineering, 21(3): 92.

Menichino, T. (1992). A cost-of-quality model for hospital laboratory. MLO Med Lab Obs. 24 (50):47-48.

Mosadeghrad, A. M. (2014). Factors influencing healthcare service quality. Int J Health Policy Manag, 3:77-89.

Olivier, D., and Seyedzadeh, J. (2006). Using the cost of poor quality to drive process improvement. Presentation at Health Care Conference Administrators, L.L.C. Retrieved from www.ehcca.com/presentations/devicecongress1/olivier_a.pdf

Omachonu, V., and Einspruch, N. (2010). Innovation in healthcare delivery systems: A conceptual framework. The Public Sector Innovation Journal, 15(1):1-20.

Omachonu, V., Sakesun, S., Einspruch, N. (2004). The relationship between quality and quality cost for a manufacturing company. International Journal of Quality \& Reliability Management, 21(3): 277 - 290

Ortiz, C. (2012). The psychology of lean improvements: Why organizations must overcome resistance and change the culture. Boca Raton, FL: CRC Press. ISBN13: 9781439878798

Palmer, C., James, B., Stat, M., \& Bayley, K. B. (2006). Cost of poor quality or waste in integrated delivery system settings. Report submitted to Agency for Healthcare Research and Quality. Rockville: Maryland.

Patton, F. and Pini, J. (2009). Lean six sigma speeds testing for hospital emergency rooms. Available at: http://www.processexcellencenetwork.com/six-sigma-quality/articles/lean-six-sigma-speeds-testing-forhospital-emergen

Pudło, P., and Szabo, S. (2014). Logistic costs of quality and their impact on degree of operating leverage. Journal of Applied Economic Sciences, IX (3):469-476.

Robbins, H. (2009). Herb Robbins shows how to identify and eliminate the eight inefficiencies in healthcare. Accessed on May 2016, Interview available at: http://www.processexcellencenetwork.com/businessprocess-management-bpm/articles/herb-robbins-shows-how-to-identify-and-eliminate-t/.

Roberts, R., Frutos P.W., Ciavarella, G.C., Gussow, L.M., Mensah, E.K., Kampe, L.M., et al.1999. Distribution of fixed vs variable costs of hospital care. JAMA, 281:644-9.

Ross, J. September, 2008. Cost of quality. Total Quality Management Word Press. Retrieved from https://totalqualitymanagement.wordpress.com/2008/09/12/cost-of-quality/

Schiffauerova, A. and Thomson, V. (2006), "A review of research on cost of quality models and best practices", International Journal of Quality \& Reliability Management, Vol. 23 No. 6, pp. 647-669. https://doi.org/10.1108/02656710610672470

Scotty, J. (September 26, 2013). Reduce the cost of quality with lean six sigma. The Pyzdek Institute. Retrieved from http://sixsigmatraining.com/leadership/reduce-the-cost-of-quality-with-lean-six-sigma.html

Shah, R. and Ward, P. (2007). Defining and developing measures of lean production. Journal of Operations Management, 25(4):785-805.

Tsai, W. H., Hwang, E. T., Chang, J. C., Lai, C. W., Lin, S. J., \& Yang, C. H. (2012). Taxonomy of cost of quality (COQ) across the enterprise resource planning (ERP) implementation phases. African Journal of Business Management, 6(3):854.

Weber, J. (December, 2013). Seven advantages of Kanban over par for hospital material management. Retrieved from http://blog.spacesaver.com/StoragesolvedwithSpacesaver/bid/93968/Seven-Advantages-of-Kanbanover-Par-for-Hospital-Material-Management

Womack, J., Byrne, A., Fiume, O., Kaplan, G., \& Toussaint, J. (2005). Going lean in health care. In D. Miller (Ed.), Institute for Healthcare Improvement (p. 15). Cambridge, Massachusetts: Institute for Healthcare Improvement

Zahar, M., El Barkany, A., \& El Biyaali, A. (2015). Cost of quality in health care: A case study in clinical laboratory. Annals of the Faculty of Engineering Hunedoara, 13(1):121.

Zimak, G. (2000). Cost of quality (COQ): Which collection system should be used? In Proceedings from American Society for Quality 54th Annual Quality Congress. Milwaukee, WI: ASQ Quality Press. 